\title{
In Silico Anticancer Activity and In Vitro Antioxidant of Flavonoids in Plectranthus amboinicus
}

\author{
Kesaktian Manurung ${ }^{1,2}$, Delmi Sulastri ${ }^{3, *}$, Nasrul Zubir ${ }^{3}$, Syafruddin Ilyas ${ }^{4}$
}

Kesaktian Manurung ${ }^{1,2}$, Delmi

Sulastri ${ }^{3, *}$, Nasrul Zubir ${ }^{3}$,

Syafruddin llyas ${ }^{4}$

'Department of Biomedical Sciences, Faculty of Medicine, Andalas University, Limau

Manis, Pauh, Padang, Sumatera Barat 25163, INDONESIA.

${ }^{2}$ Department of Pharmacy, Faculty of

Pharmacy and Health Sciences, Sari Mutiara Indonesia University, Helvetia Tengah,

Medan Helvetia, Medan, Sumatera Utara

20124, INDONESIA

${ }^{3}$ Department of Nutrition, Faculty of

Medicine, Andalas University, Limau Manis,

Pauh, Padang, Sumatera Barat 25176,

INDONESIA.

${ }^{4}$ Department of Biology, Faculty of

Mathematic and Natural Sciences, Sumatera

Utara University, Padang Bulan, Medan Baru

Medan, Sumatera Utara 20155, INDONESIA.

\section{Correspondence}

\section{Delmi Sulastri}

Department of Nutrition, Faculty of

Medicine Andalas University, Limau

Manis, Pauh, Padang, Sumatera Barat

25176, INDONESIA

E-mail: delmisultasri@yahoo.com

History

- Submission Date: 03-09-2020;

- Review completed: 01-10-2020;

- Accepted Date: 05-10-2020.

DOI : 10.5530/pj.2020.12.215

Article Available online

http://www.phcogj.com/v12/i6s

Copyright

(C) 2020 Phcogj.Com. This is an openaccess article distributed under the term of the Creative Commons Attribution 4.0 International license.

\section{ABSTRACT}

Background: Plectranthus amboinicus (Lour.) Spreng is a plant that has a high flavonoid content The leaves of Plectranthus amboinicus (Lour.) Spreng contain many flavonoids Chrysoeriol, Cirsimaritin, Eriodictyol, Luteolin, Rutin, Salvigenin, Thymoquinone, Quercetin, Apigenin, and 5-O-Methyl-Luteolin. Objectives: To determine the antioxidant activity and anticancer activity of flavonoid compounds contained in Plectranthus amboinicus (Lour.) Spreng. Methods: Anticancer activity testing was carried out by in silico against several cancer receptors and antioxidant activity testing was carried out by in vitro using the 1,1-Diphenyl-2-Picryhydrazil method. The results showed that the flavonoid compounds contained in Plectranthus amboinicus (Lour.) Spreng have similar anticancer activity to the reference molecule at the P-Glycoprotein-1, Cyclin Dependent Kinase-2, and Phosphoinositide-3-Kinase receptors, as well as better anticancer activity than the reference molecule for the Cyclooxygenase-2 and Phosphoenolpyruvate Carboxykinase receptors. Results: The antioxidant activity of the extract gave an Inhibitory Concentration $50 \%$ value of $9.77 \mu \mathrm{g} / \mathrm{mL}$, the flavonoid compounds contained in Plectranthus amboinicus (Lour.) Spreng gave an Inhibitory Concentration 50\% value that lower than the extract, which ranged from $6.92 \mu \mathrm{g} / \mathrm{mL}$ to $8.50 \mu \mathrm{g} / \mathrm{mL}$. Flavonoids in Plectranthus amboinicus (Lour.) Spreng anticancer activity by in silico molecular docking and antioxidant activity by in vitro 1,1-Diphenyl-2-Picryhydrazil method. Conclusions: All the flavonoid compounds contained in the ethanolic extract of Plectranthus amboinicus (Lour.) Spreng leaves exhibit very strong anti-cancer and antioxidant activity, which results in ethanolic extract of Plectranthus amboinicus (Lour.) Spreng leaves have very strong antioxidant activity. Key words: Anticancer, Antioxidant, In Silico, In Vitro, Flavonoid.

\section{INTRODUCTION}

Exposure to carcinogenic substances will damage Deoxyribose Nucleic Acid (DNA). If the Deoxyribose Nucleic Acid (DNA) repair fails, it will lead to cancer. ${ }^{1}$ Based on research results from the International Agency for Research on Cancer, the most common cancers in Indonesia are breast, cervical, lung, ovarian, rectum, thyroid, colon, liver and nasopharyngeal cancer. ${ }^{2}$ The main strategy of choice in the treatment of colon cancer is chemotherapy with 5-fluorouracil (5-FU) but it is very toxic to other normal tissues. ${ }^{3-4}$

The diversity of plants in Indonesia is one of the important opportunities in developing Indonesia potential in the era of globalization. ${ }^{5}$ Natural sources of antioxidants that come from food ingredients are found in spices, leaves, seeds, vegetables. ${ }^{6}$ Most sources of natural antioxidants are plants, which are generally phenolic compounds, including the flavonoid group. Flavonoids that are active as antioxidant and anticancer compounds. The leaves of Plectranthus amboinicus (Lour.) Spreng contain many flavonoids Chrysoeriol, Cirsimaritin, Eriodictyol, Luteolin, Rutin, Salvigenin, Thymoquinone, Quercetin, Apigenin, and 5-O-Methyl-Luteolin.?

The ability of flavonoids as antioxidants has been widely researched recently, because flavonoids have the ability to reduce free radicals. This study aims to determine the antioxidant activity of the ethanol extract of Plectranthus amboinicus (Lour.) Spreng leaves and 10 pure flavonoid compounds contained in the leaves of Plectranthus amboinicus (Lour.) Spreng by in vitro. The research was also continued by testing the anticancer activity of 5-fluorouracil and 10 pure flavonoid compounds contained in the leaves of Plectranthus amboinicus (Lour.) Spreng against several cancer receptor by in silico.

\section{MATERIALS AND METHODS}

\section{Materials}

Sample, Methanol (Merck), Chrysoeriol (Sigma Aldrich), Cirsimaritin (Sigma Aldrich), Eriodictyol (Sigma Aldrich), Luteolin (Sigma Aldrich), Rutin (Sigma Aldrich), Salvigenin (Sigma Aldrich), Thymoquinone (Sigma Aldrich), Quercetin (Sigma Aldrich), Apigenin (Sigma Aldrich), and 5-O-Methyl-Luteolin (Sigma Aldrich), 1,1-Diphenyl2-Picryhydrazil (Sigma Aldrich).

Tools

Personal Computer Asus Core i9 RAM 16 GB ROM 1 TB, Software PLANTS, Software MARVIN SKETCH, Software Statistical Package for Social Sciences version 26 year 2019, Drying Cabinet, Glassware (Iwaki). 


\section{Preparation of Extract}

Leaves of Plectranthus amboinicus (Lour.) Spreng were obtained from Dolok Marlawan Village, Jorlang Hataran District, Simalungun Regency, North Sumatra Province, Republic of Indonesia, Postal Code 21172. Determination of plant materials was carried out at Herbarium Medanense, Faculty of Mathematics and Natural Sciences, University of North Sumatera. The samples used were collected, washed, drained, sliced, dried, blended, and sieved. A total of 500 grams of powder were added $3.75 \mathrm{~L}$ of $96 \%$ ethanol, left for 5 days while stirring frequently, filtered the extract, readded $1.25 \mathrm{~L}$ of $96 \%$ ethanol, left for 5 days while stirring frequently, filtered the extract, concentrated with a rotary evaporator, evaporated in a water bath until a crude extract was obtained. ${ }^{8}$

\section{In Silico Anticancer Test}

The molecule obtained from the Protein Data Bank is a combination of the native ligand and the binding pocket molecule. Native ligand molecule ATP and binding pocket molecule P-Glycoprotein-1 with protein code 1MV5; native ligand molecule IMN and binding pocket molecule Cyclooxygenase-2 with protein code 4COX; native ligand molecule 1YG and binding pocket molecule Cyclin Dependent Kinase-2 with protein code $4 \mathrm{LYN}$; native ligand molecule $1 \mathrm{UK}$ and binding pocket molecule Phosphoinositide-3-Kinase with protein code $4 \mathrm{KZC}$; native ligand molecule GCP and binding pocket molecule Phosphoenolpyruvate Carboxykinase with protein code $1 \mathrm{KHB}$. The three dimensional conformation of native ligand molecules were redocking into the each binding pocket molecule then calculated as the Root Mean Square Deviation value is valid if it is less than $2 \AA$. The three dimensional conformation of the test molecule and the reference molecule were docking to binding pocket molecule, and the binding energy value of each conformation of the molecule of the test molecule and the reference molecule were obtained in the various binding pocket molecule. ${ }^{9}$

\section{In Vitro Antioxidant Test}

Free radical solution 1,1-diphenyl-2-picryhydrazil with a concentration of $200 \mu \mathrm{g} / \mathrm{mL}$ was fresh prepared, pipetted as much as $5 \mathrm{~mL}$, inserted in a $25 \mathrm{~mL}$ volumetric flask, added a certain volume of the extract solution in methanol or flavonoid compound solution in methanol with a concentration of $100 \mu \mathrm{g} / \mathrm{mL}$ (obtained a concentration of $2.5 \mu \mathrm{g} / \mathrm{mL}$ to $20 \mu \mathrm{g} / \mathrm{mL}$ ), diluted with methanol, allowed for 60 minutes, measured at a wavelength of $516 \mathrm{~nm}$, calculated the Inhibitory Concentration 50\% with Statistical Package for Social Sciences version 26 year 2019. ${ }^{10}$

\section{RESULTS AND DISCUSSIONS}

\section{In Silico Anticancer Test}

The native ligand molecule was extracted from the protein obtained from the protein data bank and redocking native ligand molecule against the binding pocket molecule to determine the validity of the binding pocket molecule. The results of validation of the binding pocket molecule validation can be seen in Table 1 .
The in silico molecular docking process of all native ligand compounds in each binding pocket molecule was valid, because the value of Root Mean Square Deviation obtained was less than $2 \AA .{ }^{11}$ So that the entire binding pocket molecule can be used to docking the test compound molecule by in silico. The binding energy of the test molecule and reference molecule as a result of the molecular docking test can be seen in Table 2.

The binding energy value by in silico docking result of the whole test molecule were lower than the reference molecule against the Cyclooxygenase-2 and Phosphoenolpyruvate Carboxykinase. This means that all the test molecules have a stronger interaction than the reference molecules against the Cyclooxygenase- 2 and Phosphoenolpyruvate Carboxykinase. On the P-Glycoprotein-1, Cyclin Dependent Kinase-2, and Phosphoinositide-3-Kinase, the test molecule gave results that were not significantly different from the reference. This means that all the test molecules have a similar interaction to the reference molecules against the P-Glycoprotein-1, Cyclin Dependent Kinase-2, and Phosphoinositide-3-Kinase. The binding energy resulted by in silico molecular docking is reflection of the affinity between the test molecule and the binding pocket molecule. ${ }^{12}$ The lower the binding energy value, the stronger the interaction between the test molecule and the binding pocket molecule. ${ }^{13}$

The in silico molecular docking results of flavonoid compounds in the glycoside form gives a lower bond energy yield than flavonoid compounds in the non glycoside form. This occurs because in silico molecular docking testing of glycoside compounds has bigger molecule (steric barrier effect), making it difficult to enter the binding pockets and difficult to bind with receptors. However, in reality in the body, most of the ether and ester after penetrate in the cell will undergo hydrolysis. So that in this study the 5-O-Methyl-Luteolin molecule is undergoes hydrolysis to become a Luteolin molecule which has better bonding energy (lower) and better bond affinity (higher). ${ }^{14}$

\section{In Vitro Antioxidant Test}

The test for the antioxidant activity of the ethanol extract of Plectranthus amboinicus (Lour.) Spreng leaves and pure flavonoid compounds contained in the ethanol extract of Plectranthus amboinicus (Lour.) Spreng leaves was carried out by the free radical scavenging method. The use of the compound 1,1-diphenyl-2picryhydrazil is a free radical that has an unpaired nitrogen atom. The reaction between 1,1-diphenyl-2-picryhydrazil with hydrogen atoms in the antioxidant will cause a color change from purple to yellow. The results of antioxidant activity of the extract and pure flavonoid compounds can be seen in Table 3 .

The results showed that the Inhibitory Concentration $50 \%$ value of the extract was higher than the pure compound, but this difference was not significantly different from the Inhibitory Concentration 50\% value compared to pure compounds. These results indicate that the antioxidant activity of the extracts and pure compounds is similar. So that the use of extracts is very effective and efficient in terms of acquisition and price, because pure compounds have a higher price because the isolation process is longer. ${ }^{15}$

Table 1: The results of validation of the binding pocket molecule validation.

\begin{tabular}{cccc}
\hline Protein Code & Native Ligand & Binding Pocket & Root Mean Square Deviation \\
\hline 1 MV5 & ATP & P-Glycoprotein-1 & $1.4634 \AA$ \\
4 COX & IMN & Cyclooxygenase- & $1.3948 \AA$ \\
4 LYN & 1 YG & Cyclin Dependent Kinase-2 & $1.6391 \AA$ \\
$4 \mathrm{KZC}$ & $1 \mathrm{UK}$ & Phosphoinositide-3-Kinase & $1.2475 \AA$ \\
$1 \mathrm{KHB}$ & GCP & Phosphoenolpyruvate Carboxykinase & $0.9942 \AA$ \\
\hline
\end{tabular}


Table 2: The binding energy of the test molecule and reference molecule as a result of the molecular docking test.

\begin{tabular}{|c|c|c|c|c|c|}
\hline \multirow{2}{*}{ Molecule } & \multicolumn{5}{|c|}{ Binding Energy } \\
\hline & 1MV5 & $4 \operatorname{COX}$ & 4LYN & $4 K Z C$ & $1 \mathrm{KHB}$ \\
\hline Verapamil & -84.68 & - & - & - & - \\
\hline Celecoxib & - & -83.18 & - & - & - \\
\hline Flavopiridol & - & - & -85.32 & - & - \\
\hline Idelalisib & - & - & - & -85.21 & - \\
\hline Metformin & - & - & - & - & -61.45 \\
\hline Chrysoeriol & -82.95 & -89.24 & -84.24 & -84.45 & -84.25 \\
\hline Cirsimaritin & -83.61 & -88.15 & -85.12 & -83.82 & -88.15 \\
\hline Eriodyctyol & -83.42 & -88.36 & -84.84 & -84.65 & -89.24 \\
\hline Luteolin & -85.06 & -89.72 & -86.09 & -85.96 & -85.14 \\
\hline Rutin & -85.84 & -88.65 & -86.55 & -85.84 & -84.64 \\
\hline Salvigenin & -83.92 & -87.26 & -85.64 & -84.51 & -87.15 \\
\hline Thymoquinone & -83.57 & -86.34 & -84.34 & -84.35 & -84.15 \\
\hline Quercetin & -86.34 & -90.35 & -88.64 & -87.23 & -89.45 \\
\hline Apigenin & -85.36 & -88.92 & -86.02 & -86.34 & -84.45 \\
\hline 5-O-Methyl-Luteolin & -81.36 & -85.34 & -81.33 & -81.34 & -82.84 \\
\hline
\end{tabular}

Table 3: The results of antioxidant activity of the extract and pure flavonoid compounds.

\begin{tabular}{ccc}
\hline Test Solution & Regression Equation & Inhibitory Concentration 50\% \\
\hline Extract & $\mathrm{Y}=4.9911 \times \mathrm{X}+1.2437$ & $9.77 \mu \mathrm{g} / \mathrm{mL}$ \\
Chrysoeriol & $\mathrm{Y}=5.8942 \times \mathrm{X}+1.3412$ & $8.26 \mu \mathrm{g} / \mathrm{mL}$ \\
Cirsimaritin & $\mathrm{Y}=6.0246 \times \mathrm{X}+1.4427$ & $8.06 \mu \mathrm{g} / \mathrm{mL}$ \\
Eriodyctyol & $\mathrm{Y}=6.3148 \times \mathrm{X}+1.4521$ & $7.69 \mu \mathrm{g} / \mathrm{mL}$ \\
Luteolin & $\mathrm{Y}=6.4127 \times \mathrm{X}+1.4684$ & $7.57 \mu \mathrm{g} / \mathrm{mL}$ \\
Rutin & $\mathrm{Y}=6.2517 \times \mathrm{X}+1.4321$ & $7.77 \mu \mathrm{g} / \mathrm{mL}$ \\
Salvigenin & $\mathrm{Y}=6.1413 \times \mathrm{X}+1.3718$ & $7.92 \mu \mathrm{g} / \mathrm{mL}$ \\
Thymoquinone & $\mathrm{Y}=5.7245 \times \mathrm{X}+1.3248$ & $8.50 \mu \mathrm{g} / \mathrm{mL}$ \\
Quercetin & $\mathrm{Y}=6.9934 \times \mathrm{X}+1.6045$ & $6.92 \mu \mathrm{g} / \mathrm{mL}$ \\
Apigenin & $\mathrm{Y}=6.8042 \times \mathrm{X}+1.5521$ & $7.12 \mu \mathrm{g} / \mathrm{mL}$ \\
5-O-Methyl-Luteolin & $\mathrm{Y}=5.7511 \times \mathrm{X}+1.3154$ & $8.47 \mu \mathrm{g} / \mathrm{mL}$
\end{tabular}

Inhibitory Concentration $50 \%$ is a number that can indicate a concentration that can inhibit $50 \%$ of free radical activity. ${ }^{15}$ Inhibitory Concentration $50 \%$ is used to compare the antioxidant activity so that the Inhibitory Concentration 50\% value is inversely proportional to the ability of antioxidants to reduce free radicals. The lower the Inhibitory Concentration $50 \%$ value, the higher the antioxidant activity. The higher the Inhibitory Concentration 50\% value, the lower the antioxidant activity. ${ }^{17}$

A substance has antioxidant properties when the Inhibitory Concentration $50 \%$ value is less than $200 \mu \mathrm{g} / \mathrm{mL}$. Antioxidants play a role in preventing free radical tissue damage by minimizing the formation of radicals, reducing or increasing breakdown. Specifically, a compound is categorized to be a very strong antioxidant for Inhibitory Concentration $50 \%$ values less than $50 \mu \mathrm{g} / \mathrm{mL}$, strong antioxidants for Inhibitory Concentration 50\% values between $50 \mu \mathrm{g} /$ $\mathrm{mL}$ to $100 \mu \mathrm{g} / \mathrm{mL}$, moderate antioxidants for Inhibitory Concentration $50 \%$ values between $100 \mu \mathrm{g} / \mathrm{mL}$ to $150 \mu \mathrm{g} / \mathrm{mL}$, and weak antioxidants for Inhibitory Concentration $50 \%$ values between $151 \mu \mathrm{g} / \mathrm{mL}$ to 200 $\mu \mathrm{g} / \mathrm{mL} .^{18}$

\section{CONCLUSIONS}

All the flavonoid compounds contained in the ethanolic extract of Plectranthus amboinicus (Lour.) Spreng leaves exhibit very strong anti-cancer and antioxidant activity, which results in ethanolic extract of Plectranthus amboinicus (Lour.) Spreng leaves have very strong antioxidant activity.

\section{ACKNOWLEDGMENT}

Researchers would like to thank the Ministry of Education and Culture through the Directorate General of Higher Education for research funding assistance with the Doctoral Dissertation Research Grant Scheme with the proposed State University is Andalas University.

\section{REFERENCES}

1. Basu AK. Review DNA Damage, Mutagenesis and Cancer. International Journal of Molecular Sciences. 2018;19(970):1-13.

2. International Agency for Research on Cancer. World Health Organization - Cancer in Indonesia. 2019. https://gco.iarc.fr/today/data/factsheets/populations/360 indonesia-fact-sheets.pdf

3. Chau I, Fakih M, García-Alfonso P, Linke Z, Casado AR, Marques EP, et al. Safety and Effectiveness of Aflibercept + Fluorouracil, Leucovorin, and Irinotecan (FOLFIRI) for the Treatment of Patients with Metastatic Colorectal Cance $(\mathrm{mCRC})$ in Current Clinical Practice: OZONE Study. Cancers. 2020;12(657):1-12.

4. Chahin $M$, Krishnan $N$, Chhatrala $H$, Shaikh M. A 5-Fluorouracil-Induced Hyperammonemic Encephalopathy Challenged with Capecitabine. 2020 Hindawi Case Reports in Oncological Medicine; 2020(4216752):1-4.

5. Suwardi AB, Navia ZI, Harmawan T, Syamsuardi S, Mukhtar E. The diversity of wild edible fruit plants and traditional knowledge in West Aceh region, Indonesia. Journal of Medicinal Plants Studies. 2019;7(4):285-90.

6. Embuscado ME. Spices and Herbs: Natural Sources of Antioxidants - a Min Review. Journal of Functional Foods. 2015;2015:1-9.

7. Arumugam G, Swamy MK, Sinniah UR. Plectranthus amboinicus (Lour.) Spreng: Botanical, Phytochemical, Pharmacological and Nutritional Significance. Molecules. 2016;21(369):1-26.

8. Abubakar AR, Haque M. Preparation of Medicinal Plants: Basic Extraction and Fractionation Procedures for Experimental Purposes. Journal of Pharmacy and Bioallied Sciences. 2020;12(1):1-10. 
9. Nerdy N. In Silico Docking Roselle (Hibiscus sabdariffa I.) Calyces Flavonoids as Antimalarial against Plasmepsin 1 and Plasmepsin 2. Asian Journal of Pharmaceutical and Clinical Research, 2017;10(10):183-6.

10. Manssouri M, Znini M, Majidi L. Studies on the antioxidant activity of essential oil and various extracts of Ammodaucus leucotrichus Coss. \& Dur. Fruits from Morocco. Journal of Taibah University for Science. 2020;14(1):124-30.

11. Cob-Calan NN, Chi-Uluac LA, Ortiz-Chi F, Cerqueda-García D, Navarrete-Vázquez G, Ruiz-Sánchez E, Hernández-Núñez E. Molecular Docking and Dynamics Simulation of Protein $\beta$-Tubulin and Antifungal Cyclic Lipopeptides. Molecules. 2019;24(18):3387-400.

12. Prasanth DSNBK, Murahari M, Chandramohan V, Panda SP, Atmakuri LR Guntupallia C. In Silico Identification of Potential Inhibitors from Cinnamon against Main Protease and Spike Glycoprotein of SARS CoV-2. Journal of Biomolecular Structure \& Dynamics. 2020;2020:1-15

13. Abdelli I, al Hassani F, Brikci SB, Ghalem S. In Silico Study the Inhibition of Angiotensin Converting Enzyme 2 Receptor of COVID-19 by Ammoides verticillata Components Harvested from Western Algeria. Journal of Biomolecular Structure and Dynamics. 2020;2020:1-14
14. Tian-Yang Wang, Qing Li, Kai-Shun Bi. Bioactive Flavonoids in Medicinal Plants: Structure, Activity and Biological Fate. Asian Journal of Pharmaceutical Sciences. 2018;13(1):12-23.

15. Rasul MG. Extraction, Isolation and Characterization of Natural Products from Medicinal Plants. International Journal of Basic Sciences and Applied Computing. 2018;2(6):1-6.

16. More GK, Makola RT. In-Vitro Analysis of Free Radical Scavenging Activities and Suppression of LPS-Induced ROS Production in Macrophage Cells by Solanum sisymbriifolium Extracts. Scientific Reports, 2020;10:6493-506.

17. Matuszewska $A$, Jaszek $M$, Stefaniuk D, Ciszewski $T$, Matuszewski t. Anticancer, Antioxidant, and Antibacterial Activities of Low Molecular Weight Bioactive Subfractions Isolated from Cultures of Wood Degrading Fungus Cerrena unicolor. 2018. PLoS ONE;13(6):e0197044.

18. Marjoni MR, Zulfisa A. Antioxidant Activity of Methanol Extract/Fractions of Senggani Leaves (Melastoma candidum D. Don). 2017. Pharmaceutica Analytica Acta. 8:557-62.

\section{GRAPHICAL ABSTRACT}
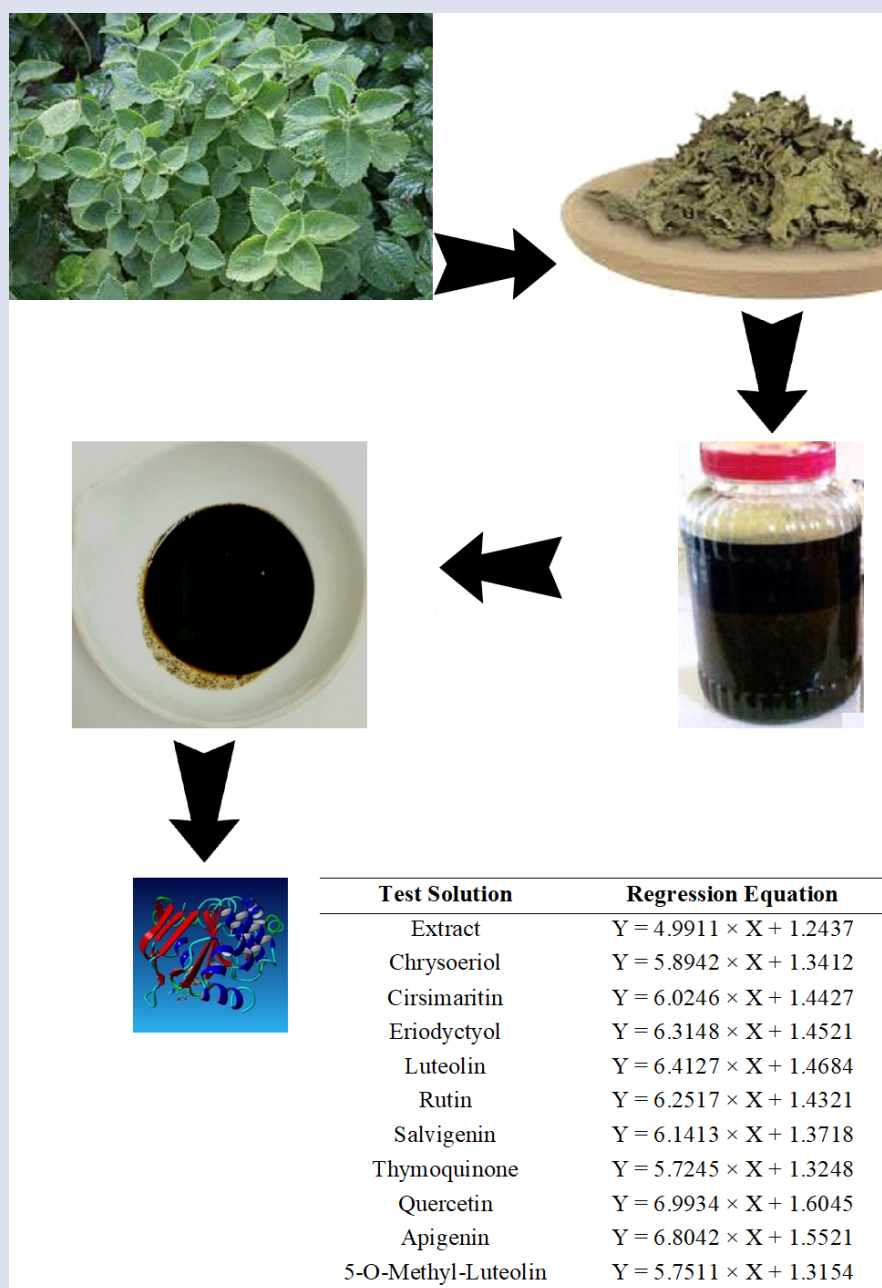

Inhibitory Concentration 50\% $9.77 \mu \mathrm{g} / \mathrm{mL}$

$8.26 \mu \mathrm{g} / \mathrm{mL}$

$8.06 \mu \mathrm{g} / \mathrm{mL}$

$7.69 \mu \mathrm{g} / \mathrm{mL}$

Luteolin

Rutin

Salvigenin

Thymoquinone

Quercetin

Apigenin

5-O-Methyl-Luteolin

$\mathrm{Y}=5.7511 \times \mathrm{X}+1.3154$

$7.57 \mu \mathrm{g} / \mathrm{mL}$

$7.77 \mu \mathrm{g} / \mathrm{mL}$

$7.92 \mu \mathrm{g} / \mathrm{mL}$

$8.50 \mu \mathrm{g} / \mathrm{mL}$

$6.92 \mu \mathrm{g} / \mathrm{mL}$

$7.12 \mu \mathrm{g} / \mathrm{mL}$

$8.47 \mu \mathrm{g} / \mathrm{mL}$ 


\section{ABOUT AUTHORS}

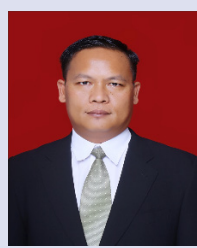

Kesaktian Manurung is a lecturer at Sari Mutiara Indonesia University in the field of biomedical, pharmacological, and natural product. He is currently honored to continue his doctoral program in Faculty of Medicine, Andalas University

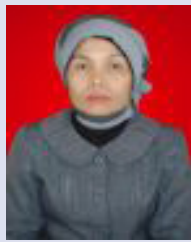

Delmi Sulastri is a professor at Andalas University. She is expert doctor in nutrition field and expert researcher in the field of biomedical and nutrition.

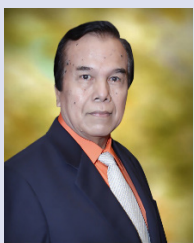

Nasrul Zubir is a professor emeritus at Andalas University. He is expert doctor in gastroenterohepatology field and expert researcher in the field of biomedical and gastroenterohepatology.

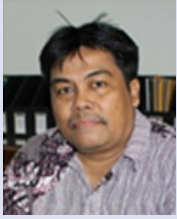

Syafruddin Ilyas is a professor at Sumatera Utara Universitas. He is an expert researcher in the biology, microbiology, cancer, and reproductive field.

Cite this article: Manurung K, Sulastri D, Zubir N, Ilyas S. In Silico Anticancer Activity and In Vitro Antioxidant of Flavonoids in Plectranthus amboinicus. Pharmacogn J. 2020;12(6)Suppl:1573-7. 